\title{
PENGUPAHAN : TINJAUAN TERHADAP PERMASALAHAN KETENAGAKERJAAN DI INDONESIA
} Ashabul Kahpi Universitas Islam Negeri (UIN) Alauddin Makassar

Email: cavon.al@gmail.com

\begin{abstract}
Labor Problems in Indonesia are classic problems that continue to show themselves to follow the times. Therefore, until now the issue has remained in the range of the limited employment opportunities, high unemployment, low labor resources, low wages and makeshift social security, followed later by demonstrations and strikes. Wages in this case occupy a separate position and become the main agenda for almost every labor movement / demonstration. The irony is that the series of policies contained in the rules in the form of Laws, Government Regulations, Ministerial Regulations and others have not / have been unable to reduce workers' resistance movements and criticism of stakeholders. The gap and imbalance of position between workers / employers and employers, as well as differences in perceptions of wages (UM) are at the core of the problems being faced and try to find solutions by the Government to this day.
\end{abstract}

Keywords, Workers / Laborers, Wages, policies

\begin{abstract}
Abstrak
Permasalahan Ketenagakerjaan di Indonesia adalah permasalahan klasik yang terus menampakkan dirinya mengikuti perkembangan zaman. Oleh sebab itu hingga saat ini permaslahan tersebut masih tetap berkisar diseputar sempitnya peluang kerja, tingginya angka pengangguran, rendahnya sumber daya tenaga kerja, upah murah dan jaminan sosial yang seadanya, terikut kemudian adalah demonstrasi dan pemogokan. Upah dalam hal ini menempati posisi tersendiri dan menjadi agenda utama nyaris disetiap pergerakan/demonstrasi buruh. Ironinya, rentetan kebijakan yang tertuang dalam aturan baik berupa Undang-undang, Peraturan Pemerintah, Peraturan Menteri dan lainnya ternyata belum/tidak mampu mereduksi gerakan resistensi kaum pekerja/buruh dan kritikan pihak berkepentingan. Kesenjangan dan ketidak seimbangan posisi antara pekerja/buruh dan pengusaha, serta perbedaan persepsi terhadap upah (UM) menjadi inti permasalahan yang tengah dihadapi dan coba dicari solusinya oleh Pemerintah hingga dewasa ini.

Kata Kunci, Pekerja/buruh, Upah, kebijakan
\end{abstract}




\section{PENDAHULUAN}

$\mathrm{D}$ itengah kondisi ketenagakerjaan Indonesia yang problematik ${ }^{1}$ dan kian kompleks, permasalahan upah senantiasa menjadi persoalan utama, terlebih Indonesia masih merupakan sebuah negara berkembang. Hal ini kian diperparah oleh keadaan angkatan kerja dan pengangguran Indonesia yang di satu sisi jumlahnya sangat banyak $^{2}$, sementara di sisi lain mutu dan dan keterampilan mereka tergolong rendah bahkan hanya sekedar mengandalkan tenaga. Keadaan ini pada gilirannya akan menjadikan issu pengupahan menjadi issu utama dalam ketenagakerjaan di Indonesia.

Permasalahan pengupahan buruh dinilai menjadi masalah pelik dan hanya terjadi di Indonesia. Berdasarkan pemaparan dari Peneliti INDEF, Enny Sri Hartati mengatakan Indonesia belum bisa menyelesaikan permasaahan buruh padahal sudah merdeka 70 tahun. ${ }^{3}$ Hal yang sejalan dengan tingkat kesejahteraan pekerja Indonesia yang justru berada pada posisi paling akhir terlepas dari permasalahan pekerja di Indonesia yang belum kompetitif.

Hal ini justru oleh sebagian kalangan dianggap ironi, sebab secara konstitusianal Undang-undang Dasar 1945 (UUD 45) telah menggariskan bahwa setiap warga negara bersamaan kedudukannya di dalam hukum ${ }^{4}$, berhak atas pekerjaan dan penghidupan yang layak bagi kemanusiaan ${ }^{5}$ dan berhak untuk hidup serta berhak mempertahankan hidup dan kehidupannya ${ }^{6}$. Dari kutipan UUD 1945 tersebut terlihat jelas bahwa ukuran kesejahteraan dilihat dari kemampuan

1 Permasalahan ketenagakerjaan akan terus bermunculan, terlebih iklim investasi di Indonesia kian terbuka luas yang tampaknya berdampak pada ikut masuknya pekerja-pekerja asing ke Indonesia. Contoh nyata yang terlihat adalah maraknya pekerja-pekerja RRT, yang berdasarkan data resmi berkisar 24.804 orang," ujar Kepala Biro Humas Kementerian Ketenagakerjaan Sahat Sinurat kepada Kompas.com, Jumat (18/5/2018). Akan tetapi, Komisioner Ombudsman, La Ode Ida mengatakan, berasarkan temuan tim di lapangan, tenaga kerja asal Tiongkok yang masuk ke Indonesia tidak terdeteksi oleh Pemerintah Pusat. Sebab, ada perbedaan data jumlah TKA antara yang dimiliki pemerintah dengan temuan Ombudsman di lapangan. Justru permasalahannya adalah sebagian besar justru unskill labour. https://news.okezone.com/read/2018/04/26/337/1891812/investigasi-ombudsman-tka-china-tanpaketerampilan-masuk-ke-indonesia-setiap-hari. diakses tanggal 20 Oktober 2018.

2 Total jumlah angkatan kerja tahun 2018 naik sebanyak 2,39 juta dari Februari 2017 menjadi 133,94 juta jiwa, dengan jumlah pengangguran sebanyak 6,87 juta dan yang bekerja sebanyak 127,07 juta jiwa. Sumber Badan Pusat Statistik, diakses tanggal 20 Oktober 2018

${ }^{3}$ http://www.tribunnews.com/nasional/2017/04/30/hanya-indonesia-yang-terus-berkutatmasalah-upah-buruh

${ }^{4}$ Pasal 27 (1) Undang-Undang Dasar 1945

${ }^{5}$ Pasal 27 (2)

${ }^{6}$ Pasal 28A 
warga negara untuk menjalani kehidupan dan pekerjaan yang layak. Bahwa setiap warga negara pada dasarnya memiliki keinginan untuk berkehidupan dan bekerja secara layak agar mendapatkan kehidupan yang sejahtera, maka sejahtera adalah hak bagi setiap warga yang harus dilindungi oleh Negara, yang justru bagi kalangan pekerja diukur berdasarkan upan dan penghasilan. Oleh sebab itu bagi pekerja, pemenuhan hal tersebut tidak terlepas dari posisinya sebagai pekerja, terutama masalah pengupahan.

Baik Pemerintah maupun masyarakat (pekerja) dalam posisinya masingmasing memiliki hubungan yang berkesinambungan yang amat sulit untuk dipisahkan, pada posisinya pemerintah berkewajiban meyediakan peluang dan lapangan kerja, sedangkan masyarakat harus memenuhi syarat dan kewajiban sebagai tenaga kerja. Oleh karena itu UUD 1945 menekankan pentingnya kehidupan sejahtera, dan kemampuan pemerintah menangani kuota lapangan kerja yang terus meningkat, termasuk ke dalamnya kebijakan pengupahan.

Secara konvensional kebijakan sistem pengupahan di beberapa negara didasarkan pada falsafah ekonomi negara tersebut dan hal ini mendasari dua teori ekstrim, yaitu : pertama, berdasarkan teori Karl marx berupa nilai dan pertentangan kelas yang pada umumnya dilaksanakan di negara penganut paham sosialis. Kedua, didasarkan pada pertambahan produk marginal berdasarkan asumsi pasar/perekonomian bebas. Sistem kedua ini banyak dipakai di negara berpaham kapitalis. ${ }^{7}$

Di Indonesia sendiri, tidak jelas menganut satu di antara dua sistem tersebut, atau bisa berada di antara kedua sistem yang ada ${ }^{8}$. Namun jika dasarnya adalah kandungan pasal-pasal pengupahan sebagai yang termuat dalam UU. No. 13 Tahun $2003^{9}$, jelas menyatakan bahwa pengaturan kebijakan pengupahan berada dan ditentukan oleh pemerintah, maka hal ini sejalan dengan pandangan teori pertama yang intinya berpedoman pada pandangan Karl Mark, bahwa tingkat upah dalam sistem ekonomi sosialisme ditentukan oleh pemerintah. Pemerintah akan menentukan berapa tingkat upah yang akan diterima oleh seorang pekerja. Pertimbangan penentuan upah oleh pemerintah pada dasarnya adalah sesuai dengan kepentingan pemerintah, yang dapat beraspek ekonomi, politik atau lainnya.

${ }^{7}$ T. Gilarso, Pengantar Ilmu Ekonomi Mikro, (Yogyakarta: Kanisius, 2003), h. 217

${ }^{8}$ Ahmad,S.Ruky.. Manajemen Penggajian dan Pengupahan untuk Karyawan Perusahaan. (Jakarta, Gramedia Pustaka, 2006), h. 31 Pasal 88

${ }^{9}$ Lihat Undang-Undang Republik Indonesia Nomor 13 tahun 2003 Bab X Bagian Kedua 
Pada dasarnya persoalan upah berada pada ranah pribadi antara pekerja dan pemberi kerja, sehingga besarannya tergantung pada kesepakatan kedua belah pihak. Persoalan yang muncul kemudian adalah terkait dengan posisi tawar masing masing, bahwa pekerja/buruh berada pada posisi yang lebih membutuhkan sehingga menempatkan pekerja/buruh pada posisi yang rendah, maka yang terjadi justru para pekerja hanya diminta untuk menyetujui hal-hal yang diinginkan oleh pemberi kerja/pengusaha, termasuk upah.

Akan tetapi menurut Adriani $^{10}$, perbedaan posisi tawar tersebut mengharuskan dan menjadi alasan pemerintah untuk ikut berperan dalam bentuk campur tangan (melalui beberapa uu dan peraturan) langsung pada mekanisme ketenagakerjaan. Tujuannya adalah untuk memberikan perlindungan kepada pekerja/buruh dari ancaman eksploitasi tenaganya dan secara umum menyelesaikan dan menyelaraskan hubungan antara pemberi kerja dan pekerja.

Meski demikian, kebijakan-kebijakan pemerintah dalam usaha menjembatani dan menangani permasalahan pengupahan dinilai oleh beberapa kalangan (utamanya kaum pekerja) belum maksimal, bahkan dinilai berat sebelah dan cendrung lebih menguntungkan pengusaha. Oleh sebab itu, ketimpangan pengupahan inilah yang terus disuarakan oleh buruh/pekerja dan terus menjadi tuntutan utama kepada pemerintah disetiap peringatan hari Buruh Internasional (may day) pada tanggal 1 Mei, disamping tuntutan lain yang tetap saja berhubungan dengan masalah upah, semisal : penghapusan/pencabutan aturan tertentu tentang upah (PP, Perpres, Permen dll), outsoucing, maupun tenaga kerja $\operatorname{asing}^{11}$

\section{Permasalahan}

Upah bagi para pekerja merupakan faktor penting karena merupakan sumber untuk membiayai dirinya dan keluarganya. bagi tenaga kerja yang berpendidikan upah merupakan hasil investasi (rate of return) sumber daya manusia pada dirinya, dan bagi kelompok tertentu upah melambangkan status sosial dan penghargaan bagi (hasil) pekerja. Bagi pengusaha, upah dan

${ }^{10}$ Adriani, presentasi Pandangan Pemerintah Terhadap Sistem Pengupahan. Peer Review RUU Sistem Pengpahan DPD RI. Hotel Bluesky. Jakarta, 23 Mei 2017.

${ }^{11}$ Peringatan May Day tahun ini diwarnai oleh adanya tiga tuntutan yang akan disuarakan kaum buruh yang disebut Tritura Plus. Tuntutan tersebut adalah, (1) Turunkan harga beras, listrik, BBM, dan bangun ketahanan pangan dan ketahanan energi. (2). Tolak upah murah, cabut Peraturan Pemerintah (PP) Nomor 78 Tahun 2015 tentang Pengupahan dan menambah item kebutuhan hidup layak (KHL), (3) Tolak tenaga kerja asing (TKA) buruh kasar dari China serta cabut Peraturan Presiden (Perpres) Nomor 20 Tahun 2018 terkait TKA. https://www.liputan6.com/news/read/3495346/rayakan-may-day-150-ribu-buruh-kepung-istanahari-ini Diakses tanggal 20 Oktober 2018. 
keseluruhan biaya tenaga kerja (labour cost) merupakan biaya yang menentukan kelangsungan perusahaan dan mempengaruhi kembalinya investasi, atau biaya produksi yang harus ditekan serendah mungkin ${ }^{12}$; Bagi pemerintah, upah merupakan variabel ekonomi makro seperti inflasi, kesempatan kerja, pengangguran, pemerataan pendapatan, dan pertumbuhan secara umum. Oleh sebab itu dari berbagai sudut pandang tersebut upah merupakan kebijakan ekonomi sosial dan politik, sebagian instrumen, dan efektivitasnya sangat tergantung pada situasi ekonomi dan pasar kerja daerah/sektor ${ }^{13}$ serta kebijakankebijakan pemerintah,

Atas dasar pandangan tersebut, Pemerintah sebagai yang diketahui merupakan lembaga yang berkepentingan, baik bagi kesejahteraan pekerja sebagai warga negara, maupun terhadap kelangsungan hidup perusahaan, telah berusaha membuat berbagai kebijakan-kebijakan di sektor ketenagakerjaan, lebih khusus lagi masalah pengupahan.

Beberapa aturan-aturan, baik berupa undang-undang maupun peraturan dan Keputusan telah dikeluarkan antara lain; PP No. 8/1981 tentang Perlindungan Upah; Peraturan Menteri Tenaga Kerja Nomor PER-01/MEN/1999 tentang Upah Minimum sebagaimana diubah dengan Keputusan Menteri Tenaga Kerja dan Transmigrasi Nomor KEP.226/MEN/2000 tentang Perubahan Pasal 1, Pasal 3, Pasal 4, Pasal 8, Pasal 11, Pasal 20, dan Pasal 21 Peraturan Menteri Tenaga Kerja Nomor PER - 01/MEN/1999, Keputusan Presiden Nomor 107 Tahun 2004 tentang Dewan Pengupahan; Keputusan Presiden Nomor 84/P Tahun 2009; Permenakertrans No, 7 Tahun 2013 Tentang Upah Minimum; Peraturan Pemerintah Nomor 78 Tahun 2015 tentang Pengupahan Peraturan Menteri Ketenagakerjaan (Permenaker) No 21/2016 tentang Aturan Hidup Layak yang mulai berlaku per Juli 2016, Permenaker No. 1 Tahun 2017 Tentang Struktur dan Skala Upah, yang sekaligus menggantikan peraturan sebelumnya yang juga terkait pengupahan, yakni Kep.49/MEN/IV/2004 tentang Ketentuan Struktur dan Skala Upah, dan tentu saja yang sementara disiapkan adalah RUU No.... Tahun 2017 Tentang Sistem Pengupahan.

Namun demikian, dinamika ketenagakerjaan yang berjalan mengikuti perkembangan zaman akan tetap memunculkan persoalan-persoalan baru, yang memberi pilihan antara mempertahankan aturan lama atau membuat aturan baru.

\footnotetext{
${ }^{12}$ Zaeni Ashadie, Hukum Kerja: Hukum Ketenagakerjaan Bidang HubunganKerja, (Jakarta; Raja Grafindo Persada, 2007), h. 68

${ }^{13}$ Swasono, Yudo dan Sulistyaningsih, Metode perencanaan tenaga kerja : tingkat nasional, regional dan perusahaan, (Yogyakarta : BPFE, 1983), h. 14-16
} 
Meminjam kalimat Soeprayitno ${ }^{14}$ (Anggota Dewan Pengupahan nasional) dalam ulasannya terhadap PP 78/2015, menyatakan bahwa “ (PP 78/2015) TIDAK IDEAL (karena banyak kelemahan) tapi TERBAIK (saat ini)'. Artinya persoalan terkait upah akan senantiasa ada, namun yang lebih penting dari itu adalah membuat perangkat-perangkat hukum yang sedapat mungkin mampu mengakomodir kepentingan pihak-pihak yang terlibat di dalamnya atau paling tidak dapat meminimalisir konflik kepentingan. Hal yang sama terlihat oleh DPD RI, bahwa ada sistem yang perlu disempurnakan dalam rumus pengupahan yang disebabkan oleh perbedaan kepentingan, antara pengusaha dan pekerja yang terus bergulir, untuk alasan inilah yang menjadi salah satu sebab DPD RI menginisiasi RUU Sistem Pengupahan.

\section{PEMBAHASAN}

Kelayakan upah dan kesejahteraan kaum pekerja hingga sekarang ini masih menjadi tema penting dan tuntutan utama dalam perjuangan pekerja/buruh. Baik pengusaha maupun pekerja/buruh masih terus berdebat terkait nilai dan besaran yang mesti disepakati. Belum lagi ukuran atau standar-standar hidup layak yang harus terpenuhi, sementara harga-harga kebutuhan pokok mengalami kenaikan tiap tahun.

Pada prinsipnya, membayar upah adalah kewajiban mutlak bagi pengusaha (Pasal 1602a KUHPerdata) yang dengan demikian merupakan hak bagi pekerja/buruh. Namun besaran dan bentuknya ditetapkan dalam perjanjian kerja atau bisa saja terjadi telah ada dalam peraturan majikan ${ }^{15}$, dengan demikian pekerja/buruh hanya sekedar menyetujui saja besaran dan bentuk yang telah ditetapkan oleh pihak majikan/pengusaha. Terkait bentuk upah ini, Imam Soepomo $^{16}$ menyatakan bahwa adakalanya uu/peraturan mewajibkan atau melarang majikan untuk memberikan menyediakan barang-barang tertentu sebagai pengganti atau bagian dari upah, demikian pula ada kemungkinan dalam perjanjian maupun dalam peraturan perusahaan, ketentuan upah tidak dicantumkan.

\footnotetext{
${ }^{14}$ Soeprayitno, Memahami PP 78/2015 Sudut Pandang Pengusaha. (Slide) disampaikan dalam acara Member Gathering DPN-Apindo, Jakarta, 4 Desember 2015

${ }^{15}$ Imam Soepomo, Hukum Perburuhan Bidang Hubungan Kerja, (Jakarta; Djambatan, 1990), h. 98

${ }^{16}$ Imam Soepomo, Hukum Perburuhan..., h. 98
} 


\section{Pengertian Upah}

Pengertian upah yang paling mendasar dan tidak dapat diselisihi adalah, bahwa upah merupakan hak pekerja/buruh dan kewajiban majikan/pemberi kerja. Selanjutnya wujud dari upah tersebut secara umum dapat berbentuk uang atau dalam bentuk lain sebagai penghargaan atau imbal kerja maupun prestasi yang telah dilakukan oleh pekerja/buruh. Dari sini muncul pandangan yang mempersamakan antara upah, gaji, atau bentuk penghasilan-penghasilan lain. Ketika titik tumpu upah adalah "kerja" maka keberadaan upah mengikut pada "bekerjanya seseorang pada orang lain" dalam sebuah hubungan kerja. Imam Soepomo ${ }^{17}$ menyatakan bila tiada upah, pada umumnya juga tiada hubungan kerja, misalnya pekerjaan yang dilakukan dalam hubungan gotong royong.

Beberapa kalangan telah berusaha mendefinisikan upah berdasar pada beberapa aspek dan sudut pandang, misalnya dari sudut pandang buruh, perusahaan, hukum, ekonomi dan lain sebagainya, termasuk ke dalamnya adalah bentuk upah itu sendiri. Lazimnya, upah yang diberikan kepada karyawan berwujud uang (alat pembayaran yang sah - pasal 1602-h, akan tetapi menurut pasal 1601-p KUH perdata upah itu dapat berwujud pula sebagai berikut (dengan kondisi dan syarat tertentu):

a. Makanan yang harus dimakan atau bahan pangan, bahan penerangan,

b. bahan bakar

c. Pakaian seragam atau pakaian kerja

d. Hasil perusahaan yang ditentukan bagi karyawan atau buruh

e. Pemakaian tanah tertentu

f. Pemberian upah selama masa cuti dan lain-lain.

Meski demikian, dengan merujuk pada UUK 13/2003, perwujudan upah sebagai bentuk imbal kerja adalah uang. Disebutkan sebelumnya, pengertian upah dapat dipengaruhi oleh berbagai aspek dan sudut pandang, G. Reynold seperti dikutip oleh Imam Soepomo mengemukakan bahwa $;^{18}$ Upah bagi buruh adalah uang yang diterima - atau barang dan kebutuhan hidup yang dapat terbeli/tertutupi, sedangkan bagi pengusaha upah adalah biaya produksi yang harus ditekan serendah-rendahnya, dan serikat pekerja/buruh menganggap bahwa upah adalah objek yang harus diperjuangan untuk dinaikkan.

${ }^{17}$ Imam Soepomo, Hukum Perburuhan..., h. 5

${ }^{18}$ Imam Soepomo, Pengantar Hukum Perburuhan, (Jakarta; Djambatan,1983), h. 135, Lihat juga, Halim, Ridwan. Hukum Perburuhan dalam Tanya Jawab, Cet. 2.( Jakarta: Ghalia Indonesia, 2001), h. 84 
Adapun pengertian yang dinyatakan oleh A. Syafii Jafri ${ }^{19}$ bahwa upah menurut Islam adalah pemberian atas sesuatu jasa karyawan yang telah bekerja untuk memajukan perusahaannya, jadi upah atau disebut ju'alah adalah suatu bentuk pemberian upah bagi suatu keberhasilan atau prestasi dari suatu pekerjaan. Sementara itu dari sudut pandang ekonomi, Upah adalah sebuah kesanggupan dari perusahaan untuk menilai karyawannya dan memposisikan diri dalam benchmarking dengan dunia industri. Lebih lanjut dalam Kamus Besar Bahasa Indonesia, upah diartikan sebagai pembalas jasa atau sebagai pembayaran tenaga yang sudah dikeluarkan untuk mengerjakan sesuatu. ${ }^{20}$

Undang-undang No. 13 Tahun 2003, menjelaskan "upah adalah hak pekerja/ buruh yang diterima dan dinyatakan dalam bentuk uang sebagai imbalan dari pengusaha atau pemberi kerja kepada pekerja/buruh yang ditetapkan dan dibayarkan menurut suatu perjanjian kerja, kesepakatan, atau peraturan perundang-undangan, termasuk tunjangan bagi pekerja/buruh dan keluarganya atas suatu pekerjaan dan/atau jasa yang telah atau akan dilakukan" ${ }^{21}$ Pengertian sama sebagai yang termuat dalam RUU Pengupahan $2017^{22}$

Sedangkan definisi upah menurut Peraturan Pemerintah No. 8 tahun 1981 tentang Perlindungan Upah, upah diartikan sebagai imbalan dari pengusaha kepada pekerja atau buruh untuk suatu pekerjaan atau jasa yang telah atau akan dilakukan, imbalan tersebut dalam bentuk uang yang ditetapkan menurut persetujuan atau peraturan perundang-undangan, dan dibayarkan atas dasar suatu perjanjian kerja antara pengusaha dengan pekerja atau buruh, termasuk tunjangan baik untuk pekerja atau buruh sendiri maupun keluarganya.

Merujuk pada beberapa pengertian tersebut, dapat dikemukakan bahwa upah adalah :

a. hak pekerja/buruh yang timbul akibat tenaga yang dikeluarkan, kerja/jasa yang telah atau akan dilakukan

b. kewajiban pemberi kerja/perusahaan sebagai imbal balas atas kerja/jasa buruh

c. diwujudkan dalam bentuk uang

\footnotetext{
${ }^{19}$ A. Syafi'i Jafri, Fiqh Muamalah, (Pekanbaru: Suska Press, 2008), h. 165

${ }^{20}$ Tim Penyusun Kamus Pusat Pembinaan dan Pengembangan Bahasa, Kamus Besar Bahasa Indonesia, (Jakarta: Balai Pustaka, 1994) , h. 1108.

${ }^{21}$ Republik Indonesia, Undang-undang No. 13 Tahun 2003 Tentang Ketenaga Kerjaan, Pasal 1 angka 30

22 Lihat Rancangan Undang Undang No..... Tahun 2017 Tentang Sistem Pengupahan, Pasal 1 angka 8
} 
d. berdasar pada kesepakatan dan aturan tertentu yang dibenarkan oleh hukum (perjanjian kerja, UU dll.)

e. termasuk tunjangan bagi pekerja/buruh dan keluarganya.

\section{Upaya ke arah perbaikan sistem pengupahan}

Menyorot persoalan perlindungan terhadap upah, sangat erat kaitannya dengan perlindungan hukum bidang ketenagakerjaan ${ }^{23}$ atau hak-hak pekerja/buruh pada umumnya. Mengulas UU No. 14 Tahun 1969 Tentang Ketentuan Pokok Mengenai Tenaga Kerja, Manulang ${ }^{24}$ menyatakan bahwa salah satu tujuan penting dari masyarakat pancasila adalah dengan memberikan kesempatan bagi pekerja/buruh untuk bekerja dan memperoleh penghasilan yang dapat memberikan kesejahteraan. Dalam posisi tersebut maka pekerja/buruh berhak mendapatkan perlindungan atas keselamatan, kesehatan, kesusilaan serta tindakan amoral lainnya, dalam artian pekerja/buruh harus terlindungi dari berbagai persoalan di sekitarnya yang dapat mengganggu pelaksanaan pekerjaannya.

Hingga sekarang ini, berbagai upaya dalam rangka perlindungan upah telah dilakukan, akan tetapi persoalan-persoalan pengupahan masih tetap muncul dan menjadi dinamika ketenagakerjaan. Persoalan yang sama muncul ketika kita hendak membahas penetapan upah minimum, yang dalam pandangan Adrian Sutedi ${ }^{25}$ muncul sebagai akibat belum terwujudnya satu keseragaman upah, baik secara regional/wilayah provinsi atau kabupaten/kota, baik secara sektoral maupun nasional. Justru ketidakseragaman ini masih menjadi dasar pertimbangan demi kelangsungan hidup perusahaan maupun pekerja/buruh.

Sebagai yang telah difahami, sejak campur tangan Pemerintah dalam masalah hubungan kerja, maka hukum ketenagakerjaan yang mengatur semua aspek hubungan kerja bergeser arahnya dari hubungan privat menjadi hubungan publik ${ }^{26}$, meski jaminan terhadap hak-hak pekerja/buruh dan pengusaha tetap terlindungi. Salah satu contoh untuk alasan ini adalah adanya UUK 13/2003, yang mengatur permasalah upah sebagai termuat pada pasal 88, terkhusus PP No. 78 Tahun 2015 Tentang Pengupahan (PP 78/2015).

${ }^{23}$ Eko Wahyudi, dkk., Hukum Ketenagakerjaan, (Jakarta; Sinar Grafika, 2016), h. 54

${ }^{24}$ Sendjun H. Manulang, Pokok-pokok Hukum Ketenagakerjan di Indonesia, (Jakarta; Rineka Cipta, 2001), h. 7-8

${ }^{25}$ Adrian Sutedi, Hukum Perburuhan (Jakarta; Sinar Grafika, 2009), h. 142-144

${ }^{26}$ Sendjun H. Manulang, Pokok-pokok Hukum..., h. 13 
Menurut Widodo Suryandono ${ }^{27}$ Intervensi terhadap bidang ketenagakerjaan harus dilakukan pemerintah, sebab pemerintah berkepentingan untuk menyelaraskan antara upah layak dan pencapaian produktifitas kerja.

Akan tetapi sama seperti sebelum-sebelumnya, kriteria upah yang dinyatakan di dalam penjelasan UUK 13/2003 terkait UMK masih jauh dari kata "layak", sebuah ukuran yang relatif, alasannya menurut Asri Wijayanti ${ }^{28}$ dilihat dari ketentuan yang tercantum dalam SK Menaker No. Kep81/M/BW/1995 tentang komponen kebutuhan hidup manusia. Upah dalam ketentuan ini didasarkan pada komponen hidup minimum pekerja (KHMP) dan bukan berdasar pada kebutuhan fisik minimum. Ketentuan (UMP) ini ternyata berpengaruh terhadap pemenuhan hidup layak, terlebih bagi mereka yang sudah berkeluarga, di tengah harga kebutuhan pokok yang terus melonjak.

Melihat kenyataan bahwa ketentuan terkait upah yang termuat di dalam UUK ternyata menyisakan permasalahan, ketidak sempurnaan atau dengan bahasa lain masih memerlukan penjelasan dan pengaturan lebih lanjut, maka Upaya kearah penyempurnaaan upah terus dilakukan pemerintah. Salah satunya adalah dengan menerbitkan PP 78/2015. Namun hal yang tak jauh berbeda ketika PP 78/2015 muncul adalah penolakan dari kaum pekerja/buruh.

Alasan yang dikemukakan adalah :

a. Serikat pekerja tidak dilibatkan dalam penetapan upah minimum, padahal yang paling berkepentingan terhadap upah adalah buruh. Hal ini dipandang bertentangan dengan UUK 13/2003 tentang Ketenagakerjaan, UU No. 21 tahun 2000 tentang Serikat Pekerja/Buruh dan Konvensi ILO No. 87 tentang kebebasan berserikat.

b. Dibanding negara lain di Asean, UM Indonesia masih lebih rendah

c. PP ini didalangi "pengusaha hitam". Dalam paket ekonomi jilid I s.d III, Pengusaha sudah mendapatkan semua kemudahan yang mereka inginkan. Serikat pekerja pun mendukung langkah pemerintah untuk melindungi dunia usaha dengan penurunan tarif listrik untuk industri, gas untuk industri, dan memberikan bantuan/kemudahan bagi pengusaha yang tidak melakukan PHK terhadap pekerja. Tetapi dalam paket ekonomi jilid IV, yang diterima kaum pekerja seperti susu dibalas air tuba, Dengan kata lain,

${ }^{27}$ Widodo Suryandono, h. 100

${ }^{28}$ Asri Wijayanti, Hukum Ketenagakerjaan Pasca Reformasi, (Jakarta; Sinar Grafika, 2009), h. 104-105 
pemerintah telah membuat kebijakan yang berorientasi terhadap upah murah. Kebijakan seperti ini curang dan tidak adil bagi buruh.

d. Formula kenaikan upah bertentangan dengan konstitusi. Bahwa berdasarkan UUD 1945 Pasal 27 ayat (2) "tiap-tiap warga negara berhak atas pekerjaan dan penghidupan yang layak bagi kemanusian, dan Pasal 28D ayat (2) "setiap orang berhak untuk bekerja serta mendapat imbalan dan perlakuan yang adil dan layak dalam hubungan kerja. Hal yang sama juga ditegaskan dalam UU UUK, setiap pekerja/buruh berhak memperoleh penghasilan yang memenuhi penghidupan yang layak bagi kemanusiaan. Namun PP No 78/2015 memuat bahwa Formula kenaikan upah minimum ditetapkan berdasarkan inflasi dan pertumbuhan ekonomi, hal ini mengakibatkan penetapan upah minimum tidak lagi berdasarkan KHL (Kebutuhan Hidup Layak); dan telah mereduksi kewenangan Gubernur serta peran Serikat Pekerja/Serikat Buruh dalam penetapan upah minimum.

e. Persoalan jangka pendek dijawab dengan jangka panjang. Krisis ekonomi seperti sekarang ini, kemungkinan hanya akan berlangsung 1 - 2 tahun. Ancaman PHK besar-besaran juga tidak terbukti. Potensi PHK, seperti yang pernah disampaikan (pekerja yang dirumahkan, jam kerja yang dikurangi, tidak ada lagi lembur), perlahan mulai kembali normal. Maka solusinya bukan mengeluarkan RPP tentang Pengupahan. Sebab Peraturan Pemerintah maupun undang-undang bisa berlaku hingga 20 tahun, bahkan 30 tahun $^{29}$

Meski ditentang oleh serikat buruh dan berbagi kelompok masyarakat, akan tetapi pemerintah tetap saja mengesahkan PP 78/2015, tepatnya di bulan Oktober 2015. Dalam hal ini pemerintah bersikukuh dan berkeyakinan bahwa PP 78/2015 diperlukan demi kepastian berusaha, kepastian hukum, dan menjauhkan politisasi upah minimum dalam pemilihan kepala daerah. Alasan yang mendasari pemerintah pada waktu itu adalah, bahwa pemerintah membutuhkan waktu sekira 12 tahun melakukan survei dan pembahasan dengan melibatkan berbagai pihak. Belum lagi alasan pemerintah bahwa Peraturan yang mengatur sebelas jenis pengupahan tersebut, merupakan kelanjutan proyek fleksibilisasi pasar kerja yang direncanakan sejak 1995, sebagai syarat pencairan utang kepada Dana Moneter Internasional (IMF). Lebih jauh lagi bahwa PP 78/2015 diterbitkan pemerintah mengacu kepada Paket Kebijakan Ekonomi Jilid IV, Pemerintah dalam hal ini

${ }^{29}$ Disarikan dari https://www.bantuanhukum.or.id/web/5-alasan-tolak-pp-pengupahanpenjelasan-lengkap/, diakses tanggal 22 Oktober 2018 
menitikberatkan pada persoalan ketenagakerjaan, yaitu mendorong pengupahan yang adil, sederhana, dan terproyeksi.

Dalam sudut pandang pengusaha, keberadaan PP ini merupakan angin segar, sebab formula baku dalam PP 78/2015 mengikat seluruh pemangku kepentingan, terutama pemerintah daerah agar tidak mempolitisasi isu upah minimum buruh ini demi kepentingan politik praktis mereka. Sudah menjadi rahasia umum bahwa banyak kepala daerah dan calon kepala daerah yang menjanjikan kenaikan upah minimum sesuai tuntutan buruh. Mereka berharap langkah itu menuai dukungan politik dari kalangan buruh yang memang jumlahnya sangat signifikan untuk memenangi kontestasi pemilihan kepala daerah.

Kenaikan upah minimum yang dijanjikan kepala daerah ternyata menjadi beban bagi pengusaha. Sebab, besaran kenaikannya merupakan hasil kompromi politis, tidak didasarkan pada kalkulasi kondisi ekonomi dan kondisi keuangan masing-masing perusahaan. Itulah mengapa, PP Pengupahan ini cukup melegakan pengusaha, setidaknya upah minimum tidak lagi menjadi komoditas politik. ${ }^{30}$

Pada prinsipnya, di satu sisi kehadiran PP 78/2015 adalah merupakan perwujudan amanah UUK 13/2003 terkait regulasi dasar pengupahan, yang oleh Marcus dibagi kedalam dua bagian besar yaitu, mekanisme penetapan upah dan perlindungan upah ${ }^{31}$ : pertama; mekanisme penetapan upah, berupa UM ditingkat provinsi dan kab/kota, penetapan upah melalui perundingan kolektif, struktur dan skala upah dan peninjauan secara berkala, kedua; perlindungan upah, yang termuat dalam pasal 88 ayat (2), berupa kewenangan pemerintah untuk menetapkan kebijakan pengupahan untuk melindungi pekerja/buruh. Namun demikian kalangan yang antipati terhadap PP ini menganggap, bahwa Pujian berlebihan terhadap PP 78 Tahun 2015 dengan menawarkan struktur skala upah justru memperlihatkan lepasnya tanggungjawab dan perlindungan negara untuk memastikan terpenuhinya hak-hak pekerja/buruh utamanya pendapatan buruh yang stabil

\footnotetext{
${ }^{30}$ Dirangkum dari http://sp.beritasatu.com/tajukrencana/pp-pengupahan-demi-buruhdan-pengusaha/100719, diakses tanggal 22 Oktober 2018.

${ }^{31}$ Markus Sidauruk, Kebijakan pengupahan di Indonesia: Tinjauan Kritis dan Panduan Menuju Upah Layak, (Jakarta: Bumi Intitama, Sejahtera, 2013), h. 9.
} 
Oleh sebab itu, kewenangan pemerintah menetapkan kebijakan pengupahan khususnya penetapan upah minimum terlihat dari tujuan yang hendak dicapai yaitu meningkatkan $:^{32}$

a. Pemerataan pendapatan

b. Daya beli

c. Perubahan struktur biaya

d. Produktifitas nasional

e. Ethos dan disiplin kerja

f. Kelancaran komunikasi pekerja dan pengusaha

Menarik untuk disimak, bahwa lima tahun sebelum keluarnya PP 78, sistem pengupahan sudah dikritik oleh berbagai kalangan ${ }^{33}$. Para penggiat perburuhan mengaitkan problem pengupahan dengan tanggung jawab negara, karakter industri dan kelayakan upah buruh maupun calon buruh. Masalahmasalah tersebut berkisar pada ${ }^{34}$ :

a. upah minimum yang ditetapkan kerap jauh dari nilai riil kebutuhan hidup layak (KHL). Angka-angka statistik upah minimum di beberapa daerah memang memperlihatkan upah minimum setara atau lebih tinggi dari KHL. Namun, rumusan penetapan angka KHL sebenarnya merujuk pada sejumlah jenis barang yang ditetapkan pemerintah dan negosiasi di dewan pengupahan. Karena itu, pada kurun waktu 2013 muncul tuntutan agar terjadi revisi komponen menjadi 80 hingga 122 komponen. Pekerja/buruh menyadari, bahwa upah minimum menjadi tolak ukur perhitungan jenis-jenis upah lainnya, seperti upah lembur, pesangon, dan pembayaran tunjangan lainnya. Seyogyanya mereka berpartisipasi dalam hiruk-pikuk penentuan upah minimum.

b. bagi buruh di bawah mandor atau supervisor, upah minimum seringkali menjadi upah maksimum. Upah minimum maupun jenis pengupahan lainnya sama-sama bergantung pada hasil negosiasi. Di sini terdapat dua persoalan, yakni masa kerja buruh yang tidak

\footnotetext{
32 Widodo Suryandono, Pengupahan dan Jaminan Sosial, dalam Aloysius Uwiyono dkk, Asas-asas Hukum Perburuhan, (Jakarta; Raja Grafindo Persada, 2014), h. 102

${ }^{33}$ Kritikan dan penolakan telah menjadi bagian sejarah pengupahan di Indonesia bahkan sejak zaman Belanda, Puncak krisis pertama kali (oleh organisasi buruh) terjadi pada tahun 1922 ketika pekerja/buruh menuntut kenaikan upah. Lihat dalam Djumadi, Sejarah Keberadaan Organisasi Buruh di Indonesia, (Jakarta; Rajawali Grafindo Persada, 2005), h. 20

$34 \mathrm{http}: / /$ majalahsedane.org/kebijakan-pengupahan-masalah-dan-beberapa-pilihan/ diakses tanggal 23 Oktober 2018
} 
diperhitungkan sebagai upah dan karena ikatan kerja buruh bersifat kontrak jangka pendek (harus diperbaharui). Sehingga meskipun telah bekerja bertahun-tahun, maka masa kerjanya selalu di bawah satu tahun, justru jenis-jenis hubungan kerja yang memangkas masa kerja ini semakin lumrah dipraktikkan di berbagai sektor dan jenis industri.

c. beberapa negara di Asia mengaitkan upah minimum dengan tunjangan sosial maupun sistem pengendalian harga, di Indonesia upah minimum menjadi satu-satunya tumpuan pendapatan. Dengan upah minimum itulah berbagai keperluan hidup ditanggung. Para buruh harus berhemat dengan sejumlah komoditas yang mengalami kenaikan rutin (paling tidak) sebanyak dua kali dalam setahun, yaitu di awal tahun dan menjelang hari raya Idul Fitri. Harga beberapa komoditas pun akan mengalami kenaikan menjelang libur dan masuk sekolah atau ketika terjadi kenaikan harga dasar listrik dan bahan bakar minyak.

d. kebijakan pengupahan bersifat pukul rata kepada semua jenis usaha formal dengan modal negeri maupun luar negeri. Ketika upah minimum ditetapkan, seluruh usaha formal wajib menjalankan ketentuan tersebut. Ketentuan penangguhan upah minimum yang amat sulit dilaksanakan hanya dapat dipenuhi oleh perusahaan-perusahaan formal besar. Indonesia menyamaratakan jenis-jenis industri agar patuh pada satu sistem pengupahan. Prinsip penyamarataan tersebut berlaku pula dalam soal bantuan permesinan dan modal untuk dunia usaha. Hasilnya adalah usaha-usaha dalam negeri dengan pasar lokal kian tergusur oleh perusahaan-perusahaan besar dengan modal asing.

\section{Rancangan Undang Undang Tentang Sistem Pengupahan (RUU 2017)}

Adalah menarik untuk sedikit membahas RUU pengupahan pada bagian akhir tulisan ini dengan alasan berikut :

a. RUU ini adalah bagian program Legislasi Nasional (prolegnas) 2015 201935, dengan demikian akan berakhir pada tahun 2019 (atau dilanjutkan pada Prolegnas berikutnya), sehingga menarik untuk dinantikan pengesahannya;

b. Meski termasuk Prolegnas 2015-2019, nyatanya RUU tentang pengupahan ini telah dilakukan dan dipersiapkan oleh pemerintah sejak tahun 2003 dengan nama Rancangan Undang-Undang Sistem

${ }^{35}$ http://peraturan.go.id/ruu-tentang-sistem-pengupahan.html 
Pengupahan Nasional (sedikit berbeda dengan RUU 2017 yang tanpa kata "Nasional") sebagai acuan pelaksanaan pengupahan bagi perusahaan. ${ }^{36}$

c. Setelah digodok selama 12 tahun (2003 - 2015), yang muncul ternyata bukanlah undang-undang melainkan PP 78/2015 tentang pengupahan

d. RUU ini mencabut keberlakuan pasal 88 sampai dengan pasal 98 UUK 13/2003 PP 78/2015 terkait pengaturan upah

e. Dikembalikannya variabel Kebutuhan Hidup Layak (KHL), yang justru tidak dipergunakan dalam PP 78/2015 (akan ditinjau setiap 5 tahun berdasarkan Permenaker No. 21 Tahun 2015), padahal sebelum PP 78/2015 berlaku, penetapan upah minimum setiap tahun dilaksanakan dengan melakukan survei KHL. ${ }^{37}$. Sementara RUU ini memuat atau mengembalikan KHL tersebut dalam salah satu pasalnya misalnya pasal 43 ayat (1). Bahwa variabel KHL inilah yang merupakan salah satu tema utama tuntutan pekerja/buruh.

f. RUU ini merupakan RUU Usul Inisiatif DPD RI, bersama dengan RUU lain seperti penyusunan RUU tentang Ketahanan Keluarga, dan penyusunan pandangan atas RUU tentang Sistem Nasional Ilmu Pengetahuan dan Teknologi ${ }^{38}$

g. Pada tahun 2015 draft RUU tentang pengupahan telah rampung dan siap di ajukan ke meja Presiden RI untuk ditandatangani, ${ }^{39}$ sementara pada tahun yang sama ribuan buruh yang tergabung dalam Kongres Aliansi Serikat Buruh Indonesia (KASBI) menggelar aksi unjuk rasa di depan Istana Negara, Jakarta. Para buruh dari berbagai daerah tersebut menuntut dihapuskannya rencana pengesahan Rancangan UndangUndang (RUU) Pengupahan yang dinilai tak berpihak pada kaum buruh $^{40}$.

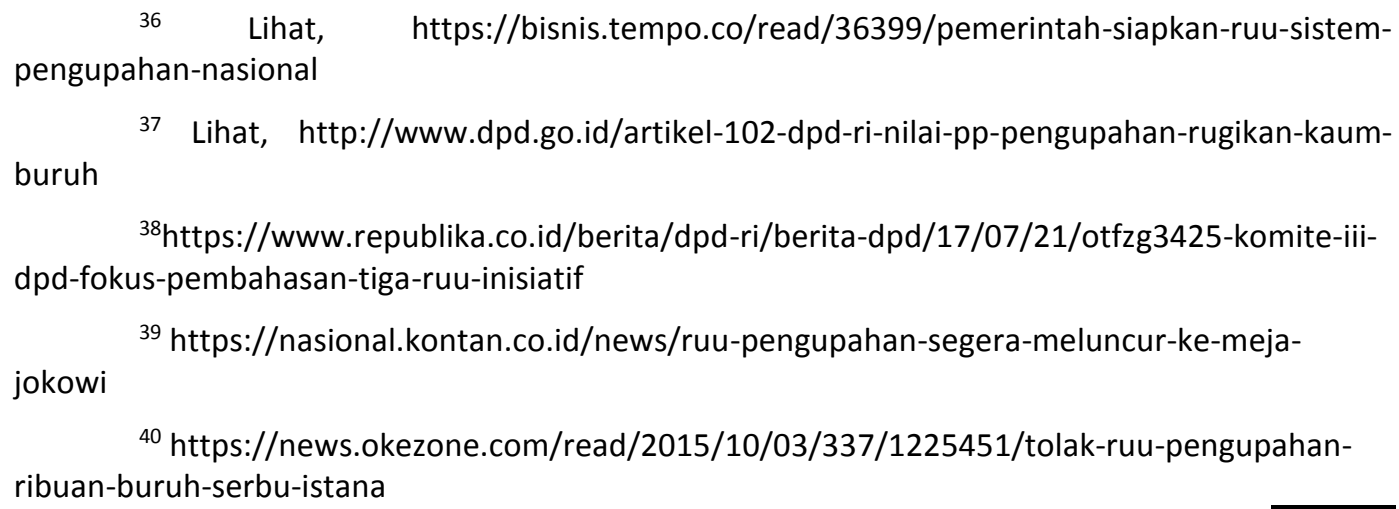

Lihat, https://bisnis.tempo.co/read/36399/pemerintah-siapkan-ruu-sistempengupahan-nasional

37 Lihat, http://www.dpd.go.id/artikel-102-dpd-ri-nilai-pp-pengupahan-rugikan-kaumburuh

${ }^{38}$ https://www.republika.co.id/berita/dpd-ri/berita-dpd/17/07/21/otfzg3425-komite-iiidpd-fokus-pembahasan-tiga-ruu-inisiatif

${ }^{39}$ https://nasional.kontan.co.id/news/ruu-pengupahan-segera-meluncur-ke-mejajokowi

${ }^{40}$ https://news.okezone.com/read/2015/10/03/337/1225451/tolak-ruu-pengupahanribuan-buruh-serbu-istana 
h. Akhirnya berdasar pada poin c dan g tersebut, muncul pertanyaan, “apakah RUU pengupahan 2017 (prolegnas 2015 - 2019) yang diinisiasi oleh DPD adalah sama dengan RUU yang disiapkan sejak tahun 2003, atau RUU pengupahan 2017 merupakan RUU yang baru ?, atau apakah draft RUU (2003) pengupahan yang siap diajukan untuk ditandatangani oleh Presiden akhirnya diberlakukan juga dengan nama PP 78/2015 dan bukan undang-undang (akibat penolakan pekerja/buruh) ?

Latar belakang RUU 2017 menyatakan antara lain, bahwa isu pengupahan masih menjadi persoalan utama di Indonesia, maraknya unjuk rasa menuntut kenaikan upah minimum, sementara upah minimum yang terlalu tinggi juga akan meningkatkan harga produk sehingga sulit bersaing di pasaran, dan peraturan terkait pengupahan saaat ini belum terintegrasi dalam satu payung hukum berbentuk undang-undang. Adapun inti dari RUU sitem pengupahan ini memuat 13 bagian yaitu : Latar Belakang, Tujuan, Ruang Lingkup, Penghasilan yang Layak, Kebijakan pengupahan, Perlindungan Upah, Upah Minimum, Kesepakatan Upah, Hal yang diperhitungkan dengan Upah, Pengenaan denda dan Pemotongan Upah, Perselisihan Pengupahan, Sanksi Administratif dan Ketentuan Pidana. ${ }^{41}$ Oleh sebab itu, berkaca dari pandangan dan permasalan upah tersebut, maka dalam pandangan Dewan Perwakilan Daerah RI (DPD) undang undang di Indonesia hendaknya dibentuk berdasar pada fungsi dasar upah, yaitu menjamin kehidupan yang layak bagi pekerja dan keluarganya, mencerminkan imbalan atas hasil kerja seseorang, dan menyediakan intensif untuk mendorong peningkatan produktifitas kerja pekerja/buruh. Disamping itu, konsep peraturan pengupahan juga harus melihat konteks integratif yang merupakan satu kesatuan sistem kesejahteraan pekerja, karena pada akhirnya peningkatan kesejahteraan pekerja bukan hanya upah, namun terkait pula dengan implementasi sistem jaminan sosial di perusahaan dari segala aspeknya ${ }^{42}$

\section{PENUTUP}

Sistem upah merupakan kebijakan dan strategi yang menentukan kompensasi yang diterima pekerja. Kompensasi ini merupakan bayaran atau upah yang diterima oleh pekerja sebagai balas jasa atas hasil kerja mereka. Pekerja/buruh menganggap bahwa pengupahan merupakan masalah yang penting

${ }^{41}$ Tim Ahli DPD RI, Intisari RUU Sistem Pengupahan

${ }^{42}$ DPD RI, Kerangka Acuan Uji Sahih Komite III DPD RI Terkait RUU Sistem Pengupahan. Jakarta, 2012, h. 3 
karena menyangkut keberlangsungan dan kesejahteraan hidup mereka beserta keluarganya, sehingga permasalah ini kian menjadi isu sensitif dibanding permasalahan ketenagakerjaan lainnya. Isu-isu dikriminasi dan kesenjangan sosial bisa muncul karena adanya perbedaan upah, unjuk rasa dan mogok kerja sudah menjadi trend dalam menanggapi kebijakan pengupahan, baik kebijakan itu dari tingkat perusahaan maupun aturan hukum yang dikeluarkan oleh pemerintah. PP 78/2015 yang mencoba meregulasi dan menjembatani permasalahan ini tampaknya sama seperti aturan sebelumnya - sama mendapatkan resistensi dari kalangan pekerja/buruh - dan penerimaan yang setengah hati oleh kalangan pengusaha. Namun yang menjadi catatan, bagi sebagian kalangan PP 78/2015 ini sekaligus menandai Indonesia menganut sistem upah fleksibel, yang justru menguat pada kurun waktu 2000-an, yang selanjutnya menjadi satu kesatuan dengan peraturan perundangan ketenagakerjaan maupun peraturan lain yang muncul kemudian. Hal yang tampak nyata dalam Instruksi Presiden Nomor 3 Tahun 2006 mengenai Paket Kebijakan Perbaikan Iklim Investasi.

Sesungguhnya permasalahan upah berada pada wilayah privat pihak terkait yaitu pihak pekerja/buruh dan majikan/pengusaha, yang berpokok pada perbedaan persepsi terhadap "upah" berikut jenis dan besarannya. Perbedaan persepsi inilah yang terus bergulir hingga "memperkuat" posisi pemerintah untuk urug rembuk dan campur tangan, tersebab hanya penguasalah berikut kekuasaannya yang mampu (dengan daya paksa) mendudukkan pihak-pihak yang berselisih paham. Namun seperti yang terlihat campur tangan pemerintah dalam hal ini tetap mendapat kritikan dan resistensi, akibat adanya bias kepentingan pada salah satu pihak.

ini pihak-pihak berkepentingan tengah menanti pengesahan RUU baru dalam masalah pengupahan, yaitu RUU sistem pengupahan 2017 yang diinisiasi DPD RI, muncul harapan berbagai pihak bahwa RUU ini mampu menjawab permasalahan pengupahan yang selama ini terus bergulir, dan terlepas dari pandangan DPD RI bahwa PP 78/2015 belum mampu mewujudkan kesejahteraan utamanya bagi pekerja/buruh dan justru merugikan buruh, namun pada nyatanya Indonesia memang membutuhkan perangkat aturan di bidang ketenagakerjaan yang minim penolakan dari kalangan buruh dan diterima dengan sepenuh hati oleh kalangan pengusaha. Dengan demikian RUU ini diharapkan mampu mengetangahkan penyelesaian permasalahan pengupahan yang solutif konprehensif. 


\section{DAFTAR PUSTAKA}

A. Syafi'i Jafri, Fiqh Muamalah, Pekanbaru: Suska Press, 2008

Adrian Sutedi, Hukum Perburuhan, Jakarta; Sinar Grafika, 2009

Adriani, presentasi Pandangan Pemerintah Terhadap Sistem Pengupahan. Peer Review RUU Sistem Pengpahan DPD RI. Hotel Bluesky. Jakarta, 23 Mei 2017.

Ahmad, S. Ruky. Manajemen Penggajian dan Pengupahan untuk Karyawan Perusahaan. Jakarta, Gramedia Pustaka, 2006

Asri Wijayanti, Hukum Ketenagakerjaan Pasca Reformasi, Jakarta; Sinar Grafika, 2009

Djumadi, Sejarah Keberadaan Organisasi Buruh di Indonesia, Jakarta; Rajawali Grafindo Persada, 2005

DPD RI, Kerangka Acuan Uji Sahih Komite III DPD RI Terkait RUU Sistem Pengupahan. Jakarta, 2017,

Eko Wahyudi, dkk., Hukum Ketenagakerjaan, (Jakarta; Sinar Grafika, 2016), h. 54

Halim, Ridwan. Hukum Perburuhan dalam Tanya Jawab, Cet. 2. Jakarta: Ghalia Indonesia, 2001

Imam Soepomo, Hukum Perburuhan Bidang Hubungan Kerja, Jakarta; Djambatan, 1990

Imam Soepomo, Pengantar Hukum Perburuhan, Jakarta; Djambatan,1983

Markus Sidauruk, Kebijakan pengupahan di Indonesia: Tinjauan Kritis dan Panduan Menuju Upah Layak, Jakarta: Bumi Intitama, Sejahtera, 2013.

Rancangan Undang Undang No..... Tahun 2017 Tentang Sistem Pengupahan, Pasal 1 angka 8

Republik Indonesia, Undang-undang No. 13 Tahun 2003 Tentang Ketenagakerjaan

Sendjun H. Manulang, Pokok-pokok Hukum Ketenagakerjan di Indonesia, Jakarta; Rineka Cipta, 2001

Soeprayitno, Memahami PP 78/2015 Sudut Pandang Pengusaha. (Slide) disampaikan dalam acara Member Gathering DPN-Apindo, Jakarta, 4 Desember 2015

Swasono, Yudo dan Sulistyaningsih, Metode perencanaan tenaga kerja : tingkat nasional, regional dan perusahaan, Yogyakarta : BPFE, 1983

T. Gilarso, Pengantar Ilmu Ekonomi Mikro, Yogyakarta: Kanisius, 2003

Tim Ahli DPD RI, Intisari RUU Sistem Pengupahan. Jakarta 2017

Tim Penyusun Kamus Pusat Pembinaan dan Pengembangan Bahasa, Kamus Besar Bahasa Indonesia, Jakarta: Balai Pustaka, 1994 
Widodo Suryandono, Pengupahan dan Jaminan Sosial, dalam Aloysius Uwiyono dkk, Asas-asas Hukum Perburuhan, Jakarta; Raja Grafindo Persada, 2014

Zaeni Ashadie, Hukum Kerja: Hukum Ketenagakerjaan Bidang HubunganKerja, Jakarta; Raja Grafindo Persada, 2007

Internet

http://majalahsedane.org/kebijakan-pengupahan-masalah-dan-beberapa-pilihan/ diakses tanggal 23 Oktober 2018

http://peraturan.go.id/ruu-tentang-sistem-pengupahan.html

http://sp.beritasatu.com/tajukrencana/pp-pengupahan-demi-buruh-dan pengusaha /100719, diakses tanggal 22 Oktober 2018.

http://www.tribunnews.com/nasional/2017/04/30/hanya-indonesia-yang-terusberkutat-masalah-upah-buruh

https://nasional.kontan.co.id/news/ruu-pengupahan-segera-meluncur-ke-mejajokowi

https://news.okezone.com/read/2015/10/03/337/1225451/tolak-ruu-pengupahanribuan-buruh-serbu-istana

https://news.okezone.com/read/2018/04/26/337/1891812/investigasi-ombudsmantka-china-tanpa-keterampilan-masuk-ke-indonesia-setiap-hari. diakses tanggal 20 Oktober 2018.

https://www.bantuanhukum.or.id/web/5-alasan-tolak-pp-pengupahan-penjelasanlengkap/, diakses tanggal 22 Oktober 2018

https://www.liputan6.com/news/read/3495346/rayakan-may-day-150-ribu-buruhkepung-istana-hari-ini. Diakses tanggal 20 Oktober 2018.

https://www.republika.co.id/berita/dpd-ri/berita-dpd/17/07/21/otfzg3425-komiteiii-dpd-fokus-pembahasan-tiga-ruu-inisiatif

http://www.dpd.go.id/artikel-102-dpd-ri-nilai-pp-pengupahan-rugikankaum-buruh

https://bisnis.tempo.co/read/36399/pemerintah-siapkan-ruu-sistempengupahan-nasional

Badan Pusat Statistik, diakses tanggal 20 Oktober 2018 